\title{
Elaphostrongylus cervi (Cameron, 1931) in Red deer (Cervus elaphus): First Record in Turkey
}

\author{
Kürşat KARTAL ${ }^{1}$, Mustafa ESER ${ }^{2 *}$, Hakan GÜZEL ${ }^{3}$ \\ ${ }^{1}$ Gazi Mustafa Kemal Anatolian High School, Biology Teacher, TR-26470 Eskisehir, Turkey \\ 2 Anadolu University Open Education Faculty Health Programs, Yunusemre Campus, TR-26470 Eskisehir, Turkey \\ ${ }^{3}$ Dinar Directorate of Provincial Agriculture And Forestry, Dinar/ Afyonkarabisar, Turkey
}

\begin{abstract}
This study was carried out to determine the presence of Elaphostrongylus cervi infection found in Red deer at Eskişehir Catacık Red Deer Production Station between June-July 2020. Based on the red deer traces and signs in the study area, 32 fresh faeces of animals were collected from the places where the faeces density was found. Stool samples were examined for cestode rings macroscopically, and microscopically by sedimentation, saturated salt flotation, and Baermann Wetzel methods. Larvae were found in all the collected faeces. The larvae obtained by the Baerman technique were identified at the species level using the relevant literature. E. cervi identified in red deer with this study is the first record in our country. Thus, it will provide valuable data for the red deer in Turkey Keywords: Elaphostrongylus cervi, Red deer, First record, Eskişehir
\end{abstract}

K1z1 geyiklerde (Cervus elaphus) Elaphostrongylus cervi (Cameron, 1931): Türkiye'de İlk Kayıt

ÖZ

Bu çalş̧ma Haziran-Temmuz 2020 tarihleri arasında Eskişehir Çatacık Kızıl Geyik Üretim İstasyonu'ndaki Kızıl geyiklerde bulunan Elaphostrongylus cervi enfeksiyonunun varlı̆ıını belirlemek amacıyla yapılmıştır. Çalışma alanında bulunan Kızıl geyik iz ve belirtilerinden hareket edilerek dışkı yoğunluğunun bulunduğu yerlerden hayvanlara ait 32 taze dışk1 toplanmıştır. Dışk1 örnekleri cestod halkaları yönünden makroskobik olarak, sedimentasyon, doymuş tuzlu su flotasyon ve Baermann Wetzel yöntemleri ile mikroskobik olarak incelenmiştir. Toplanan dışkıların hepsinde larvalara rastlanmıştır. Baerman tekniği ile elde edilen larvalar ilgili literatürlerden faydalanılarak tür düzeyinde teşhis edilmiştir. Yürütülen bu çalışmayla Kızıl geyiklerde teşhis edilen E. cervi ülkemizde ilk kayıttır. Bu sebeple Türkiye'de Kızıl Geyikler için değerli bir veri oluşturacaktır.

Anahtar Kelimeler: Elaphostrongylus cervi, Kızıl geyik, İlk kayıt, Eskişehir

To cite this article: Kartal K. Eser M. Güzel H. Elaphostrongylus cervi (Cameron, 1931) in Red deer (Cervus elaphus): First Record in Turkey. Kocatepe Vet J. (2020) 13(4):433-438

Submission: $12.08 .2020 \quad$ Accepted: $30.09 .2020 \quad$ Published Online: 10.11 .2020

ORCID ID; KK: 0000-0002-0803-2635, ME: 0000-0003-1542-2989, HG: 0000-0002-5734-2891

*Corresponding author e-mail: meser961@anadolu.edu.tr 


\section{INTRODUCTION}

Elaphostrongylus cervi which is an important helminth parasite in Red Deer (Cervus elaphus) is found in muscles, brain and the epidural space of the spinal cord in many deer species including Caspian red deer (Cervus elaphus maral), Canadian deer (Cervus elaphus canadensis), Japanese deer (Cervus nippon) and roe deer (Capreolus capreolus). The intermediate hosts are various land snails (Mason, 1989). Mature parasites are 4-6 $\mathrm{cm}$ long, pale, and in thread-shaped structure. Transmission of the parasite is through the infective larvae reaching the lungs through the bloodstream. Symptoms include lung inflammation and nervous disorders in the brain (Boden 2005). This parasite is found especially in domestic, and wild ruminants in Europe, including Scotland, Australia, and North America, and has widespread (Mason 1989).

Parasites have a significant impact on wildlife populations, including reproduction and survival (Anderson 1978). Although there are many studies on the wild animals in Turkey (Uslu et al. 2008, Ac1c1 et al. 2012, Acic1 et al. 2017, Bolukbas et al. 2012, Girisgin et al. 2018, Dik and Kilınç 2015), studies on helminth infections that infect red deer are limited (Cengiz et al. 2019). So far, there has not been a study to determine the Elaphostrongylus cervi infection in red deer in Turkey.

With this first study in Turkey, it is aimed to determine the state of E. cervi infection in the red deer in Eskisehir and to contribute to the detection of the local fauna.

\section{MATERIAL and METHODS}

This study was carried out between June-July 2020 in Eskisehir (Figure 1). Based on the traces and signs of red deer in the Catacik region of Eskisehir, 32 fresh fecal samples belonging to animals from the places where the faeces density was found were taken into transparent nylon bags and recorded by numbering. The faeces obtained were brought to laboratory.

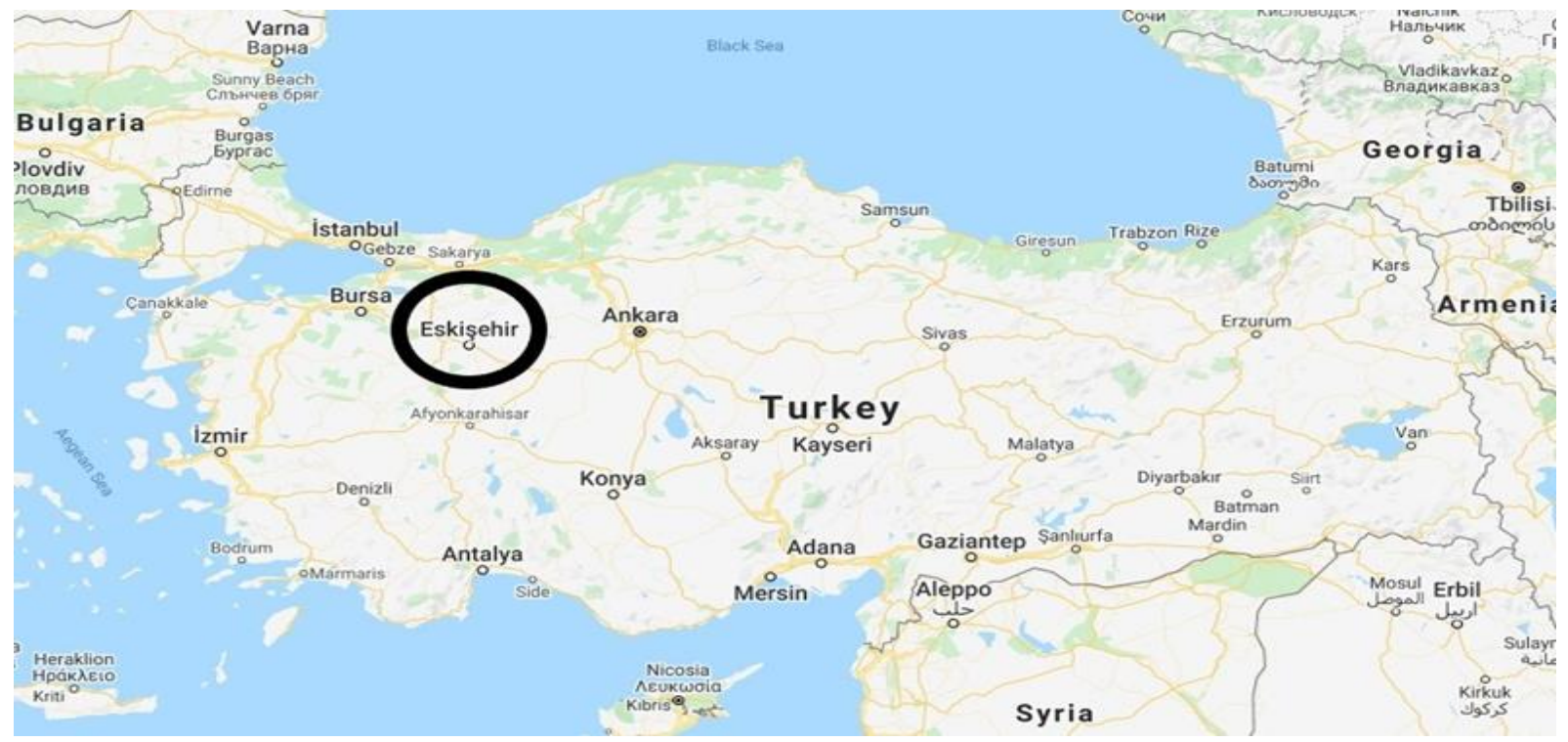

Figure 1. Location of Turkey and Eskişehir province (with black circles).

Stool samples were examined for cestode rings macroscopically, and microscopically by sedimentation, saturated salt flotation, and Baermann Wetzel methods. (Thienpont and et al. 1986). Light microscope (Olympus CX31-Olympus Imaging System LC30) was used for the identification of larvae obtained by Baerman technique. Total body length, maximum body width, tail length (from the anus to tail tip), tail extension length, and dorsal spine length were measured in a total of 50 dorsal spiny larvae in lactophenol solution.

\section{RESULTS}

In the study, it was determined that the dorsal spiny larvae, whose morphometric measurements were made, belonged to the E. cervi species. Looking at the morphometric measurements of the dorsal-spined larvae, the average total length was $408 \mu \mathrm{m}$, the width was $20 \mu \mathrm{m}$, the tail was $38 \mu \mathrm{m}$, tail extension length was $9.23 \mu \mathrm{m}$, and dorsal spine was $2.69 \mu \mathrm{m}$. (Table 1 ). 
Table 1. Measures (in $\mu \mathrm{m}$ ) of dorsal-spined larvae recovered from red deer (Cervus elaphus).

\begin{tabular}{|c|c|c|c|c|c|c|c|c|c|c|}
\hline Reference & & $\begin{array}{l}\text { This } \\
\text { study }\end{array}$ & $\begin{array}{l}\text { Baruš } \\
\text { and } \\
\text { Blazek } \\
1973\end{array}$ & $\begin{array}{l}\text { Kutzer } \\
\text { and Prosl } \\
1975\end{array}$ & $\begin{array}{l}\text { English } \\
\text { et al. } \\
1985\end{array}$ & $\begin{array}{l}\text { Demiaszkiewicz } \\
1986\end{array}$ & $\begin{array}{l}\text { Řezáč } \\
1990\end{array}$ & $\begin{array}{l}\text { Vicente } \\
\text { and } \\
\text { Gortázar } \\
2001\end{array}$ & $\begin{array}{l}\text { Morandi } \\
\text { et al., } \\
2006\end{array}$ & $\begin{array}{l}\text { Panayotova- } \\
\text { Pencheva } \\
\text { and } \\
\text { Alexandrov } \\
2008\end{array}$ \\
\hline $\begin{array}{l}\text { Total } \\
\text { length }\end{array}$ & $\begin{array}{l}\text { Mean } \\
\text { Min-Max }\end{array}$ & $\begin{array}{l}408 \\
377-437\end{array}$ & ---- & $\begin{array}{l}407 \\
364-452\end{array}$ & $\begin{array}{l}410 \\
391-460\end{array}$ & $\begin{array}{l}424 \\
382-463\end{array}$ & $\begin{array}{l}422 \\
390-459\end{array}$ & $\begin{array}{l}401 \\
365-425\end{array}$ & $390-430$ & $\begin{array}{l}423 \\
377-473\end{array}$ \\
\hline Width & $\begin{array}{l}\text { Mean } \\
\text { Min-Max }\end{array}$ & $\begin{array}{l}20 \\
16-26\end{array}$ & $18-20$ & $17-21$ & $\begin{array}{l}18 \\
16-21\end{array}$ & $\begin{array}{l}19 \\
16-24\end{array}$ & $\begin{array}{l}19 \\
16-23\end{array}$ & ----- & $18-20$ & $\begin{array}{l}20 \\
18-24\end{array}$ \\
\hline $\begin{array}{l}\text { Tail } \\
\text { extension } \\
\text { length }\end{array}$ & $\begin{array}{l}\text { Mean } \\
\text { Min-Max }\end{array}$ & $\begin{array}{l}9,23 \\
7,81-9,98\end{array}$ & ---- & ---- & ---- & ---- & ---- & ---- & ---- & ----- \\
\hline $\begin{array}{l}\text { Dorsal } \\
\text { Spine }\end{array}$ & $\begin{array}{l}\text { Mean } \\
\text { Min-Max }\end{array}$ & $\begin{array}{l}2,69 \\
2,08-2,79\end{array}$ & ---- & ----- & ---- & ---- & ---- & ---- & ---- & ---- \\
\hline Tail & $\begin{array}{l}\text { Mean } \\
\text { Min-Max }\end{array}$ & $\begin{array}{l}38 \\
34-42\end{array}$ & $26-35$ & $\begin{array}{l}43 \\
35-50\end{array}$ & $\begin{array}{l}42 \\
32-52\end{array}$ & ---- & $\begin{array}{l}44 \\
41-49\end{array}$ & ----- & ----- & $\begin{array}{l}37 \\
32-42\end{array}$ \\
\hline
\end{tabular}

First stage E. cervi larvae have rhabditiform type esophagus. The excretory hole is in the anterior ventral of the body. Genital primordium is found in the last $1 / 3$ of the body. The tail has a characteristic shape. They have a distinct triangular spine on the dorsal side parallel to the tail tip (Figure 2).

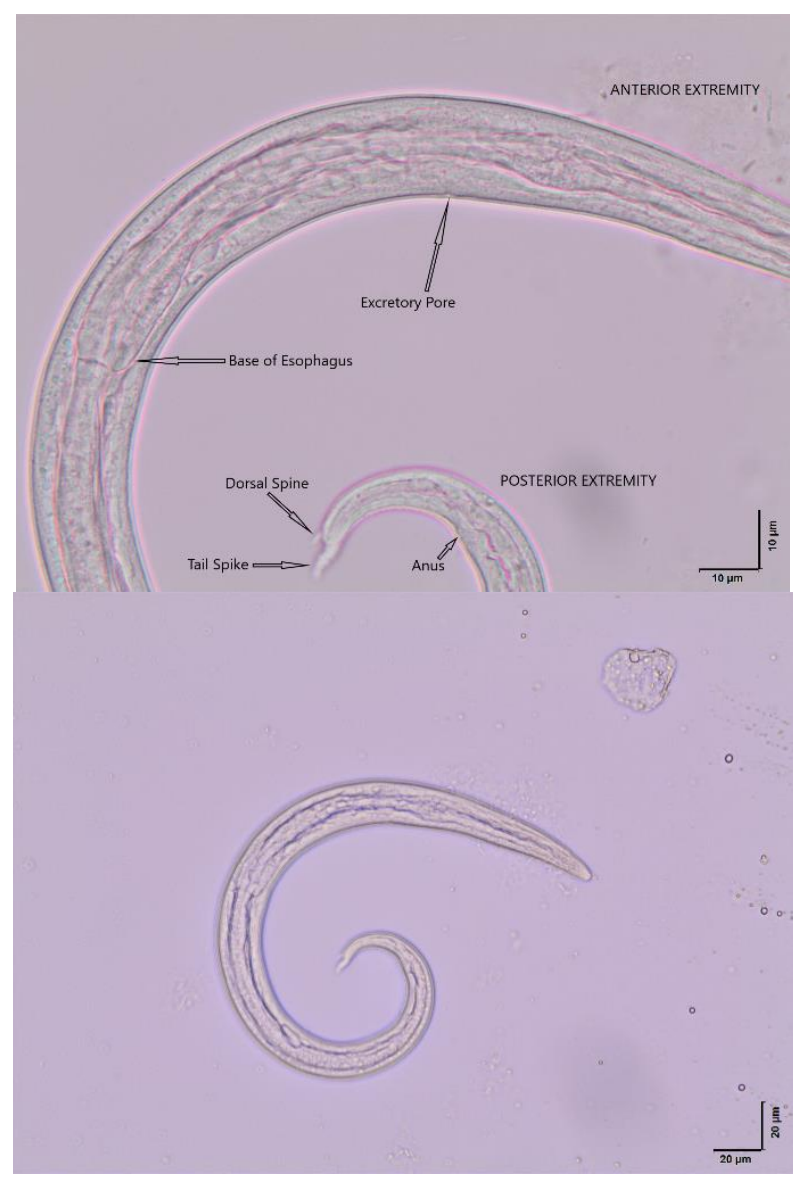




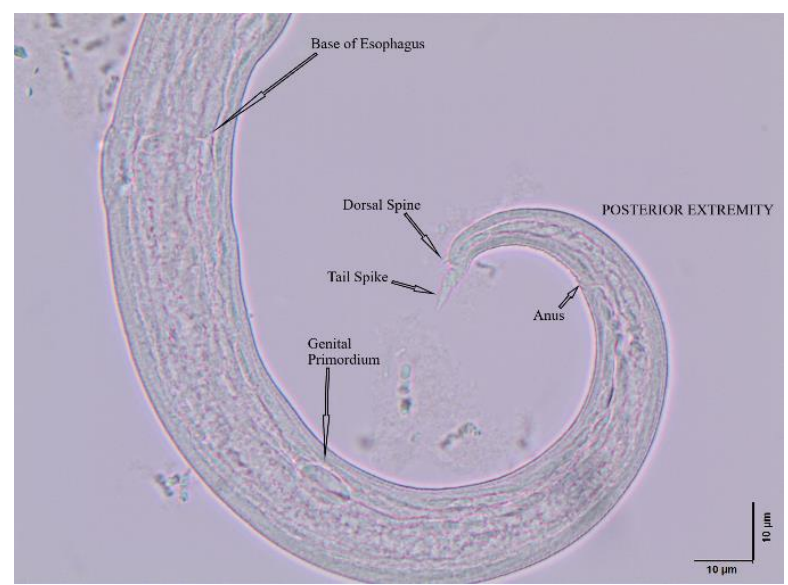

Figure 2. First stage E. cervi larva found in red deer (C. elaphus L.) from Turkey (original).

\section{DISCUSSION and CONCLUSION}

The red deer are ruminants that roam wildly in limited areas or are reared in certain protected environments in Turkey. Although there are many studies on the wild animals in Turkey (Uslu et al. 2008, Ac1c1 et al. 2012, Acic1 et al. 2017, Bolukbas et al. 2012, Girisgin et al. 2018, Dik and Kilınç 2015), studies on helminth infections that infect red deer are limited (Cengiz et al. 2019). So far, there has not been a study on E. cervi infection in Turkey.

This first study in Turkey reports the E. cervi infection in red deer in Eskisehir. First stage E. cervi larvae were found in all 32 stool samples. There are many studies abroad on E. cervi supported by both stool and necropsy examinations. (Hutsch et al. 2020, Panayotova-Pencheva and Alexandrov 2011, Alberti et al. 2011, Demiaszkiewicz et al. 2016, Sutherland 1976, Bregoli et al. 2006, Valcárcel and Garcia Romero 2002).

It was reported that $16.6 \%$ of the Red deer examined in Poland were infected with Elaphostrongylus sp (Hutsch et al. 2020). In another study, it was noted that $76.7 \%$ of the red deer were infected with E. cervi (Demiaszkiewicz et al. 2016).

In a study conducted in Italy, it was reported that $45.2 \%$ of the red deer were infected with E. cervi (Alberti et al., 2011). In the stool examination of 110 Red deer in Bulgaria, 75 (68\%) of them were found to be infected with E. cervi. In the same study, E. cervi was found in the lung tissue of 5 deer by the necropsy (Panayotova-Pencheva and Alexandrov 2011).

In a study conducted on the red deer in New Zealand, it was reported that mature E. cervi were found in connective tissue associated with skeletal muscles and its larvae in the lungs, causing various pathological lesions in these tissues (Sutherland, 1976). In Italy, mature E. cervi were diagnosed in the submeningeal region for the first time in the red deer with neurological symptoms, and cerebral nematodiasis was reported (Bregoli et al. 2006).
In a study conducted in Spain, it was reported that $31.5 \%$ of the red deer were infected with mature $E$. cervi in the central nervous system, and E. cervi was recorded for the first time in the central nervous system of red deer in Spain (Valcárcel and Garcia to Romero. 2002)

Eskişehir province, where the study was conducted, is suitable for the survival of slugs that serve as an intermediate host to helminth infections, considering that it has a continental and humid climate under the influence of the Black Sea and Central Anatolia. The field where the study was conducted is not suitable for water slugs, but because of the dry areas suitable for land slugs, it only strengthens the possibility of $E$. cervi infections in deer. (Kuligowska and Demiaszkiewicz 2010). E. cervi also causes neurological lesions in small ruminates. Therefore, the grazing of domesticated small ruminates in areas where deer are present indicates that the disease with a high prevalence in deer may also transmit to small ruminates (Alberti et al. 2011, Handeland et al. 2000). The literature research has proven that this species has not been reported in Turkey before. E. cervi, diagnosed in Red deer with this study, is reported for the first time with this study. Therefore, this research will provide valuable data for the red deer in Turkey. More research is needed to determine the parasitic fauna of the red deer that live wildly in limited areas or are reared in certain protected environments in our country.

\section{ACKNOWLEDGMENTS}

This study was supported by the Scientific Research Projects Coordination Unit of Anadolu University (Project number: 2005S062).

Ethical statement: No ethical committee approval is required as the experimental animal is not used. 
To carry out this research, the permission of the Ministry of Agriculture and Forestry dated 05/05/2020-E.19084 was obtained.

Conflict of interest : The authors declare that they have no conflict of interest.

\section{REFERENCES}

Acıcı M, Bolukbaş CS, Beyhan YE, Pekmezci GZ, Gurler AT, Umur Ş. Ectoparasites on roe deer (Capreolus capreolus) in Samsun, Turkey. Turk J Vet Anim Sci. 2012; 36(4): 456- 459. Doi:10.3906/vet-1009-471

Acıcı M, Demirtaş S, Umur Ş, Gurler AT, Bolukbaş CS. Infestations of flea species on small, wild mammals in the provinces of Aydin and Manisa in the Aegean Region, Turkey. Turk J Vet Anim Sci. 2017; 41(3): 449-452. Doi:10.3906/vet-1610-68

Alberti EG, Gioia G, Sironi G, Zanzani S. Elaphostrongylus cervi in a population of red deer (Cervus elaphus) and evidence of cerebrospinal nematodiasis in small ruminants in the province of Varese, Italy. Journal of Helminthology. 2011; 85(3), 313-318. Doi: $10.1017 /$ S0022149X10000647

Anderson RM. The regulation of host population growth by parasitic species. Parasitology. 1978; 76, 119-57. Doi: $10.1017 /$ S0031182000047739

Baruš V, Blažek K. Report on the finding of larval nematodes Elaphostrongylus cervi (Protostrongylidae) in the cranial cavity of a stag. Folia Parasitol (Praha). 1973; 20:279-280. Doi: 10.1007/s10344-008-0206-7

Bregoli M, Natale A, Cova M, Vascellari M, Pasolli C. Meningeal nematodiasis in a red deer (Cervus elaphus) in northeastern Italy - a case report. Vet. Arhiv. 2006; 76 (Suppl.), 287-293.

Bolukbas CS, Gurler AT, Beyhan YE, Acic1 M, Umur S. Helminths of roe deer (Capreolus capreolus) in the middle Black Sea region of Turkey. Parasitol Int. 2012: 61:729-730. Doi: 10.1016/j.parint.2012.06.008

Boden E. Black's Veterinary Dictionary 21. Ed. A\&C Black Publishers Limited, 38 Soho Square, London. sy. 174. 2005

Cengiz G. Tenekeci GY. Bilgen N. Molecular and morphological characterization of Cysticercus tenuicollis in red deer (Cervus elaphus) from Turkey. Acta Parasitologica. 2019; 64:652-65. doi: 10.2478/s11686019-00085-1. Doi: 10.2478/s11686-019-00085-1

Demiaszkiewicz AW. Laboratoryjna diagnostyka różnicowa Protostrongylidoz jeleniowatych. Med Welt, 1986; 42:660-663 in Polish

Demiaszkiewicz AW, Merta D, Kobielski J. Infection of red deer by parasites in South-Western Poland (Lower Silesian Wilderness). Med. Weter. 2016; 72 (5), 317-320.

Dik B, Kılınç ÖO. First case of Trichodectes pinguis (Phthiraptera: Ischnocera: Trichodectidae) on a Bear (Ursus arctos) in Turkey. Turkiye Parazitol Derg. 2015; 39, 313-315. Doi: 10.30782/uluvfd.405325
English A, Watt C, Corrigall W. Larvae of Elaphostrongylus cervi in the deer of Scotland. Vet Rec. 1985; 116:254-256

Girisgin AO, Çimenlikaya N, Bah SA, Aydın L, Girişgin O. Türkiye'de bazı yabani memelilerde bulunan dıș parazit türlerinin ilk kayıtları. Uludag Univ Vet Fak Derg. 2018; 37(2), 133-136. Doi: 10.30782/uluvfd.405325

Handeland K, Gibbons LM, Skorping A. Experimental Elaphostrongylus cervi Infection in Sheep and Goats. Journal of Comparative Pathology. 2000; 123(4):248-57. Doi: $10.1053 /$ jcpa.2000.0414

Hutsch KF, Czopowiczb M, Świsłockac M, Ratkiewiczc M, Borkowskac A, Kowalczykd R, Demiaszkiewicza AW. Patterns of parasite eggs, oocysts and larvae shedding by moose in the Biebrza marshland (NE Poland). IJP: Parasites and Wildlife. 2020; 11 191-197. doi: 10.1016/j.ijppaw.2020.02.007

Kuligowska I, Demiaszkiewicz AW. Infection of terrestial snails with larvae of Elaphostrongylus cervi (Nematoda, Protostrongylidae) in Białowieża National Park Helminthologia. 2010; 47, 1: 25 - 28. Doi:10.2478/s11687-010-0004-0

Kutzer E, Prosl H. Zur Kenntnis von Elaphostrongylus cervi Cameron, 1931. I. Morphologie und Diagnose. Wien Tierarztl Mschr. 1975; 62:258-266

Morandi F, Galuppi R, Nicoloso S, Benazzi C, Tampieri MP, Simoni P. Larvae of Elaphostrongylus cervi in a Population of Freeliving Red Deer in Italy. J Wildl Dis. 2006; 42:870-872 Doi: 10.1007/s10344-008-0206-7

Mason PC. Elaphostrongylus cervi-a review. Surveillance. 1989, 16(1): 3-10

Panayotova-Pencheva M, Alexandrov M. Morphometric characteristics of first stage Elaphostrongylus cervi (Nematoda: Protostrongylidae) larvae from Bulgaria. Eur J Wildl Res 54:771-774 2008; DOI 10.1007/s10344-0080206-7

Panayotova-Pencheva MS, Alexandrov MT. Etiopathological aspects of Elaphostrongylus cervi and Varestrongylus sagittatus infections in red deer in Bulgaria. Acta Vet Brno. 2011; 80(4): 349-352. Doi: $10.2754 / \operatorname{avb} 201180040349$

Řezáč P. Diferenciální diagnostika larev 1. stadia hlístic Varestrongylus sagittatus a Elaphostrongylus cervi. Veterinarstvi 1990; 40:311-313 in Czech. Doi: 0.1007/s10344-007-0143-x

Sutherland RJ. Elaphostrongylus cervi in Cervids in New Zealand. New Zealand Veterinary Journal. 1976; 24:11, 263-266. Doi: 10.1080/00480169.1976.34334

Thienpont D, Rochette F, Vanparijs OFJ. Diagnosing Helminthiasis by Coprological Examination. Second edition. Belgium: Janssen Research Foundation. 1986.

Uslu U, Dik B, Gokcen A. Ectoparasites of the ground squirrel (Citellus citellus (L.)) in Turkey. Turkiye Parazitol Derg. 2008; 32: 142-145

Valcárcel F, Garci'a Romero C. First report of Elaphostrongylus cervi in Spanish red deer (Cervus elaphus hispanicus). Journal of Helminthology. 2002; 76, 91-93. Doi: 10.1079/JOH2003232 
Vicente J, Gortázar C. High prevalence of large spiny-tailed protostrongylid larvae in Iberian red deer. Vet Parasitol. 2001; 96:165-170 doi:10.1016/S0304-4017(00)00425-8 Doi: 10.1007/s10344-008-0206-7 